\title{
Ultrasound-promoted organocatalytic enamine-azide [3 + 2] cycloaddition reactions for the synthesis of ((arylselanyl)phenyl-1H-1,2,3-triazol-4-yl)ketones
}

\author{
Gabriel P. Costa ${ }^{1}$, Natália Seus ${ }^{1}$, Juliano A. Roehrs ${ }^{1}$, Raquel G. Jacob ${ }^{1}$, \\ Ricardo F. Schumacher ${ }^{1}$, Thiago Barcellos ${ }^{2}$, Rafael Luque ${ }^{* 3}$ and Diego Alves ${ }^{* 1}$
}

\section{Full Research Paper}

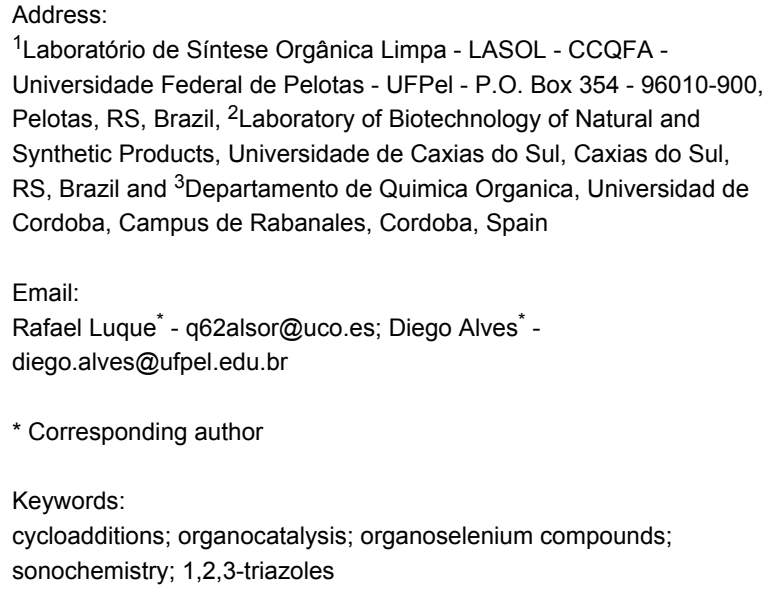

${ }^{1}$ Laboratório de Síntese Orgânica Limpa - LASOL - CCQFA Universidade Federal de Pelotas - UFPel - P.O. Box 354 - 96010-900, Pelotas, RS, Brazil, ${ }^{2}$ Laboratory of Biotechnology of Natural and Synthetic Products, Universidade de Caxias do Sul, Caxias do Sul, RS, Brazil and ${ }^{3}$ Departamento de Quimica Organica, Universidad de Cordoba, Campus de Rabanales, Cordoba, Spain

Email:

Rafael Luque* - q62alsor@uco.es; Diego Alves* -

diego.alves@ufpel.edu.br

${ }^{*}$ Corresponding author

Keywords:

cycloadditions; organocatalysis; organoselenium compounds; sonochemistry; 1,2,3-triazoles

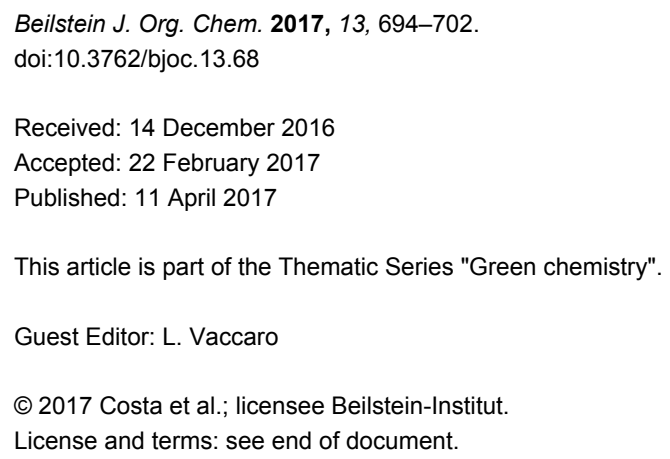

\begin{abstract}
The use of sonochemistry is described in the organocatalytic enamine-azide [3 + 2] cycloaddition between 1,3-diketones and aryl azidophenyl selenides. These sonochemically promoted reactions were found to be amenable to a range of 1,3-diketones or aryl azidophenyl selenides, providing an efficient access to new ((arylselanyl)phenyl-1H-1,2,3-triazol-4-yl)ketones in good to excellent yields and short reaction times. In addition, this protocol was extended to $\beta$-keto esters, $\beta$-keto amides and $\alpha$-cyano ketones. Selanyltriazoyl carboxylates, carboxamides and carbonitriles were synthesized in high yields at short times of reaction under very mild reaction conditions.
\end{abstract}

\section{Introduction}

Substituted 1,2,3-triazoles are an interesting class of heterocyclic compounds distinguished by their biological activities [1-3] as well as in various fields of chemistry [4-15]. The most attractive way for their preparation is the thermal 1,3-dipolar cycloaddition of alkynes and azides, introduced by Huisgen which usually gives rise to a mixture of 1,4 and 1,5-isomers
[16-19]. More recently, transition metal catalysts based on copper, ruthenium, silver and iridium salts have been used for this cycloaddition reaction [20-29].

Organocatalytic approaches based on $\beta$-enamine-azide or enolate-azide cycloadditions have been employed to synthesize 
1,2,3-triazole scaffolds [30-32]. Depending on the organocatalyst employed, different carbonyl compounds could successfully generate an enamine or an enolate, and these species react as dipolarophiles with organic azides in organocatalyzed 1,3dipolar cycloadditions. Our research group has demonstrated $\beta$-enamine-azide cycloaddition reactions for the synthesis of selenium-functionalized 1,2,3-triazoles [33-37]. Selanyltriazoyl carboxylates, carboxamides, carbonitriles or sulfones were synthesized in good to excellent yields using catalytic amounts of an organocatalyst.

Organoselenium compounds are attractive synthetic targets because of their selective reactions [38-43], photophysical properties [44-49] and interesting biological activities [50-52]. An interesting class of molecules are the selanyl-1,2,3-triazoles [53-61] which can present some biological applications. As example, 4-phenyl-1-(phenylselanylmethyl)-1,2,3-triazole A (SeTZ) demonstrated an antidepressant-like effect (Figure 1) [60]. In another example, 5-phenyl-1-(2-(phenylselanyl)phenyl)-1 $H$ 1,2,3-triazole-4-carbonitrile B (Se-TZCN) was reported to exhibit antioxidant activities in different in vitro assays (Figure 1) [36]. Selenanyl-quinone-based 1,2,3-triazoles $\mathbf{C}$ and $\mathbf{D}$ were synthesized and evaluated against six types of cancer cell lines. The synthesized compounds emerge as promising molecules for the therapeutic use of cancers overexpressing NQO1 (Figure 1) [61].

Thus, the search for efficient methods using appropriate and environmentally sound substrates for the preparation of seleniumfunctionalized 1,2,3-triazoles still remains a challenge in organic synthesis.

Ultrasonic irradiation has emerged in the past decades as a versatile tool in industrial and academic applications [62-67]. The use of sonication in organic synthesis (sonochemistry) is well documented and is generally considered as an environmentally sound energy source, comparatively less energy intensive to conventional heating and microwave irradiation, also able to reduce the number and quantities of side reaction products [6267].

There are only a few contributions describing the use of sonochemistry for the preparation of functionalized 1,2,3-triazoles [68-74]. As a recent example, our research group described the use of sonochemistry in the organocatalytic enamine-azide $[3+2]$ cycloadditions of $\beta$-oxo-amides with a range of substituted aryl azides providing and efficient access to new $N$-aryl1,2,3-triazoyl carboxamides in good to excellent yields and short reaction times of [75].

However, to the best of our knowledge, the use of sonochemistry to synthesize complex selenium-functionalized 1,2,3-triazoles via organocatalytic enamine-azide cycloaddition has not been explored to date. As a continuation of our ongoing studies towards the development of new 1,2,3-triazoles bearing organoselenium moieties, this contribution was aimed to disclose a sonochemical approach for the organocatalyzed synthesis of ((arylselanyl)phenyl-1H-1,2,3-triazol-4-yl)ketones by reacting a range of 1,3-diketones with substituted aryl azidophenyl selenides (Scheme 1).

\section{Results and Discussion}

Due to the fact that organocatalyzed $\beta$-enamine-azide cycloaddition reactions between azidophenyl aryl selenides and 1,3-diketones were not described, preliminary studies were attempted to react 2-azidophenyl phenyl selenide (1a) and 2,4pentanedione (2a) as model reaction substrates. Based on our previous report on such reaction [33], a mixture of substrates 1a $(0.3 \mathrm{mmol})$ and $2 \mathrm{a}(0.3 \mathrm{mmol})$ in DMSO $(0.6 \mathrm{~mL})$ was stirred at room temperature in the presence of $1 \mathrm{~mol} \%$ of $\mathrm{Et}_{2} \mathrm{NH}$ as organocatalyst, providing an excellent yield (98\%) of the desired product 3a after $2 \mathrm{~h}$ (conditions A, Scheme 2).

With the aim to compare the effect of different energy sources in this $\beta$-enamine-azide cycloaddition, the reaction between

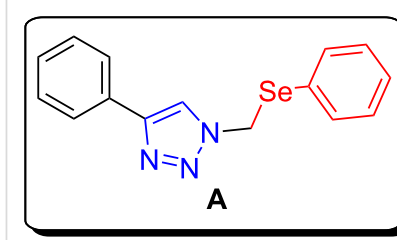

antidepressant-like effect

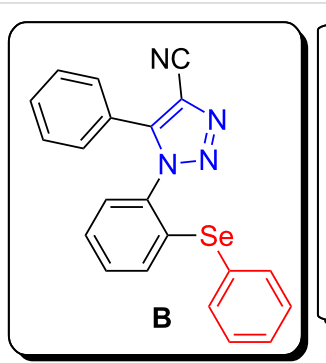

antioxidant properties

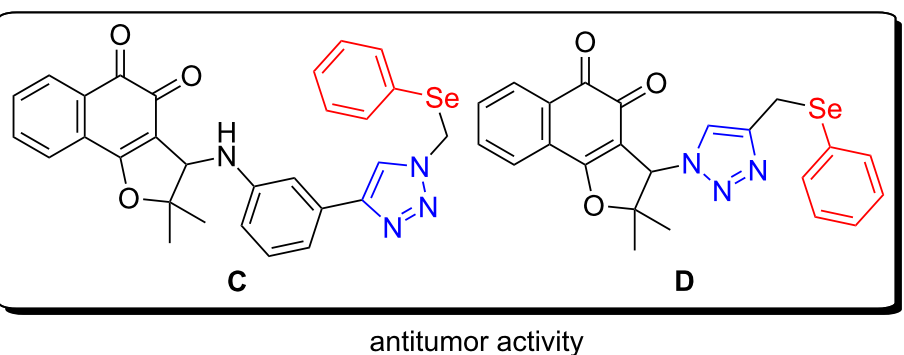

antitumor activity 
<smiles>[Mg][Se]1=CC=CC([As])=C1</smiles>

1<smiles>[R]C(=O)CC([R])=O</smiles>

2

\section{$\underset{\mathrm{Et}_{2} \mathrm{NH}(1 \mathrm{~mol} \%)}{\longrightarrow}$ \\ DMSO, rt \\ ))), $5 \mathrm{~min}$}

$\mathrm{rt}$, air

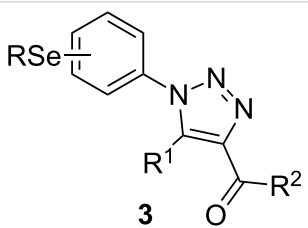

Scheme 1: General scheme of the reaction.<smiles>[N-]=[Sb]c1ccccc1</smiles>

$1 \mathrm{a}$<smiles>CC(=O)CC(C)=O</smiles>

2a

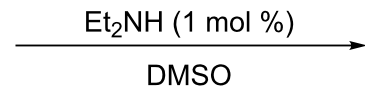

reaction conditions $\mathrm{A}$ or $\mathrm{B}$

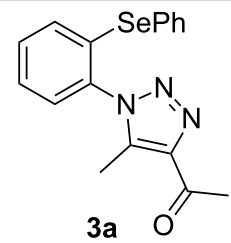

Scheme 2: Comparative study of the conventional conditions and ultrasound irradiation. Conditions A: Reaction at $25^{\circ} \mathrm{C}$ for $2 \mathrm{~h}(3 \mathrm{a}, 98 \%)$ Conditions B: Reaction under ultrasound irradiation ( $20 \%$ of the amplitude) at $25^{\circ} \mathrm{C}$ for $20 \mathrm{~min}(3 \mathrm{a}, 92 \%)$

substrates 1a and 2a in DMSO using $\mathrm{Et}_{2} \mathrm{NH}(1 \mathrm{~mol} \%)$ was also performed under ultrasound irradiation.

The reaction performed under ultrasound irradiation with $20 \%$ of the amplitude for 20 minutes (followed by TLC until the total consumption of the starting materials) yielded product 3a in $92 \%$ (conditions B, Scheme 2). Inspired by results described under conditions $\mathrm{B}$, we performed additional experiments using ultrasound irradiation with $\mathrm{Et}_{2} \mathrm{NH}$ as organocatalyst (Table 1).
Initially, substrates 1a and 2a were reacted in DMSO under ultrasound irradiation for 20 min using different amplitudes (Table 1, entries 1-4). We observed that the desired product 3a was obtained in excellent yields in all reactions. However, product yield of $\mathbf{3 a}$ decreased to $70 \%$ (Table 1, entry 5) in 10 minutes under $20 \%$ sonochemistry amplitude. To our delight, reactions performed using $40 \%$ of amplitude during 10 or 5 min gave excellent yields of selanyltriazole 3a (Table 1, entries 6 and 7). We observed that the amplitude effect could be

Table 1: Optimization of reaction conditions. ${ }^{a}$

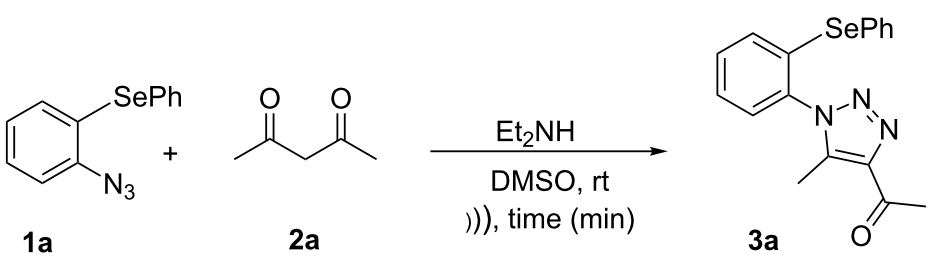

\begin{tabular}{|c|c|c|c|c|}
\hline Entry & Amplitude & $\mathrm{Et}_{2} \mathrm{NH}(\mathrm{mol} \%)$ & Time (min) & Yield 3a $(\%)^{b}$ \\
\hline 1 & 20 & 1 & 20 & 92 \\
\hline 2 & 25 & 1 & 20 & 92 \\
\hline 3 & 30 & 1 & 20 & 93 \\
\hline 4 & 40 & 1 & 20 & 96 \\
\hline 5 & 20 & 1 & 10 & 70 \\
\hline 6 & 40 & 1 & 10 & 95 \\
\hline 7 & 40 & 1 & 5 & 93 \\
\hline 8 & 40 & 0.5 & 25 & 85 \\
\hline 9 & 40 & 0.1 & 60 & n.d. \\
\hline 10 & 40 & - & 60 & n.d. \\
\hline $11^{\mathrm{c}}$ & 40 & 1 & 5 & 27 \\
\hline $12^{d}$ & 40 & 1 & 5 & 85 \\
\hline
\end{tabular}

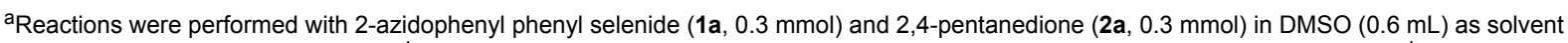

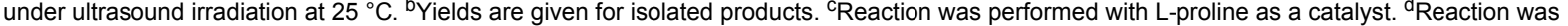
performed with pyrrolidine $(1 \mathrm{~mol} \%)$. n.d.: not detected. 
correlated to the product formation time, since that in reaction carried out in $40 \%$ of amplitude the yield of compound 3a was excellent (93\%) after 5 min reaction time (Table 1, entry 5 vs 7). A slight decrease in reaction yields could be observed after decreasing the loading of organocatalyst to $0.5 \mathrm{~mol} \%$ (Table 1 , entry 8). Finally, in blank runs (in the absence of organocatalyst) or performed using $0.1 \mathrm{~mol} \%$ of catalyst the reaction did not occur, even under sonication for $60 \mathrm{~min}$ using $40 \%$ of amplitude (Table 1, entries 9 and 10). Reactions performed with other catalysts (L-proline and pyrrolidine) gave lower yields of 3a than those using $1 \mathrm{~mol} \%$ of $^{2} t_{2} \mathrm{NH}$ (Table 1, entry 7 vs entries 11 and 12).

From Table 1, optimum reaction conditions to obtain 1-(5methyl-1-(2-(phenylselanyl)phenyl)- $1 H$-1,2,3-triazol-4yl)ethan-1-one (3a) were clearly present in entry 7 , in which a mixture of azidophenyl phenyl selenide (1a, $0.3 \mathrm{mmol})$, 2,4pentanedione (2a, $0.3 \mathrm{mmol}$ ) and $\mathrm{Et}_{2} \mathrm{NH}(1 \mathrm{~mol} \%$ ) in DMSO $(0.6 \mathrm{~mL})$ was sonicated using $40 \%$ of amplitude at room temperature for 5 minutes. In order to extend the scope of the reaction, optimum reaction conditions were extended to other 1,3diketones 2a-e with different substitution patterns (Table 2). High yields of desired 1,2,3-triazoles were obtained using $\beta$-diketones $\mathbf{2 a}, \mathbf{2 b}$ and $\mathbf{2 c}$ bearing methyl, ethyl and phenyl substituents (Table 2, entries 1-3). However, we observed that the steric hindrance effect in 2,2,6,6-tetramethyl-3,5-heptanedione 2d displays an important role in the overall reaction and only traces of product 3d was observed (Table 2, entries 1-3 vs 4). Unfortunately, no reaction occurred when cyclic $\beta$-diketone $\mathbf{2 e}$ was employed as substrate (Table 2 , entry 5 ). We next evaluated the reactivity of 2,4-pentanedione (2a) with different functionalized aryl azidophenyl selenides $\mathbf{1 b}-\mathbf{f}$ under identical reaction conditions. Aryl azidophenyl selenides containing either an EDG or an EWG on the aromatic ring delivered the expected selanyltriazoles $\mathbf{3 f}-\mathbf{i}$ in good isolated yields (Table 2, entries 6-9). However, a decrease in yield was observed when the reaction was performed with aryl azidophenyl selenide containing a $-\mathrm{CF}_{3}$ group (Table 2, entry 9). In addition, 4-azidophenyl phenyl selenide (1f) was treated with 2,4-pentanedione (2a) to afford the desired product $\mathbf{3} \mathbf{j}$ in $92 \%$ yield as a mixture of regioisomers (6:1) (Table 2, entry 10).

In addition, the possibility to perform the reaction of 2-azidophenyl phenyl selenide (1a) with $\beta$-keto-esters, $\beta$-ketoamides and $\alpha$-cyano-ketones $\mathbf{2} \mathbf{f}-\mathbf{k}$ was also investigated. The reaction conditions optimized for 1,3-diketone $\mathbf{2 a}$ were employed, but independently using as substrates ethyl acetoacetate (2f), ethyl benzoylacetate (2g), 3-oxo- $N$-phenylbutanamide (2h), 3-oxo- $N$-( $p$-tolyl)butanamide (2i), benzoylacetonitrile (2j) and 4-toluoylacetonitrile (2k). The corresponding esters $\mathbf{3 k}, \mathbf{l}$

Table 2: Scope of substrates: Variation of the aryl azidophenyl selenides 1 and 1,3-diketones $2 .^{a}$

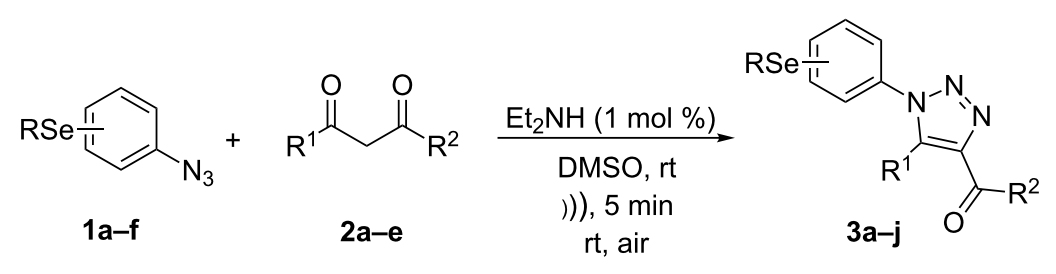

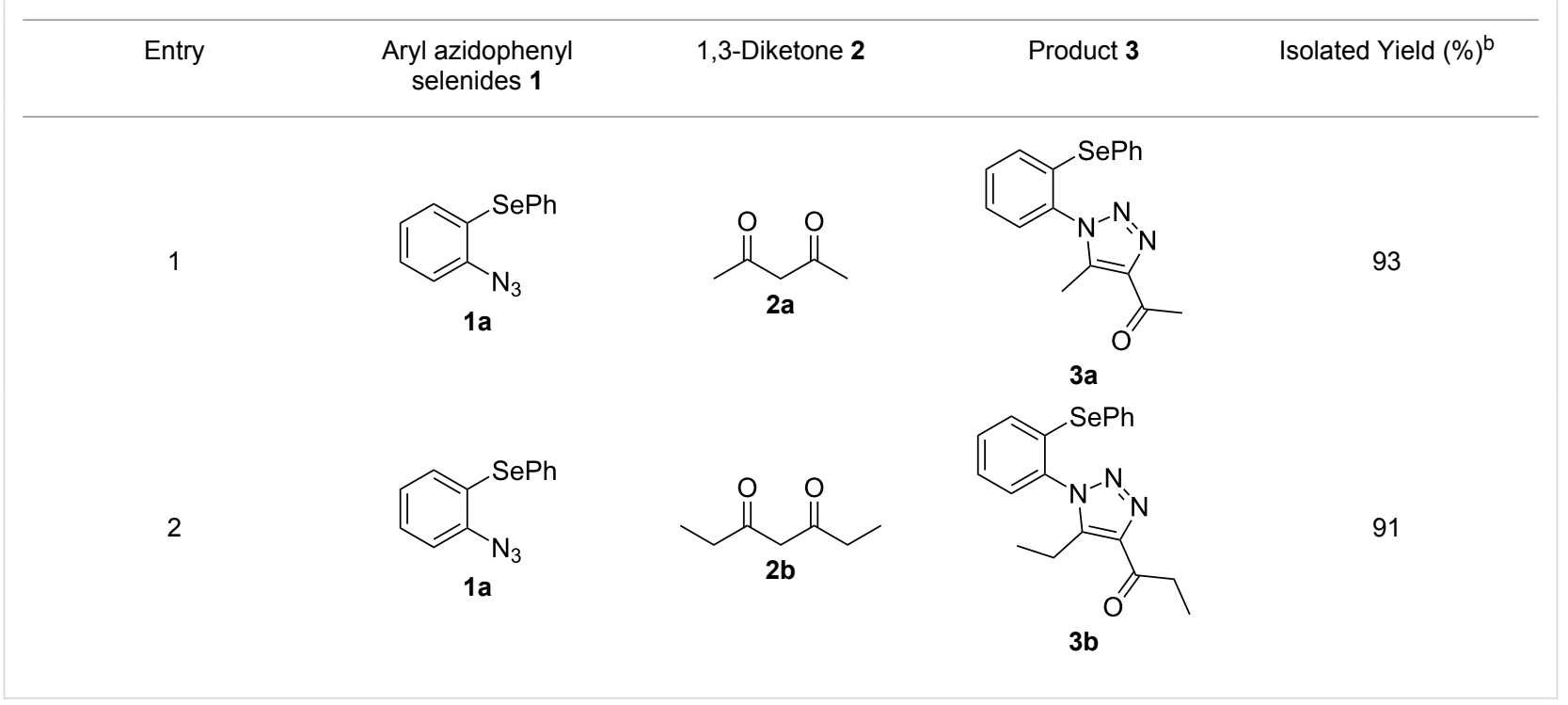


Table 2: Scope of substrates: Variation of the aryl azidophenyl selenides 1 and 1,3-diketones $2 .{ }^{\text {a }}$ (continued)

3<smiles>[N-]c1ccccc1[Se]c1ccccc1</smiles>

$1 a$<smiles>[N-]c1ccccc1Sc1ccccc1</smiles>

1a<smiles>Nc1ccccc1Sc1ccccc1</smiles>

1a<smiles>Cc1ccc([Se]c2ccccc2N)cc1</smiles>

1b<smiles>Cc1ccccc1[Se]c1ccccc1N</smiles>

1c<smiles>Nc1ccccc1[Se]c1ccc(Cl)cc1</smiles>

1d<smiles>O=C(CC(=O)c1ccccc1)c1ccccc1</smiles>

2c<smiles>CC(C)(C)C(=O)CC(=O)C(C)(C)C</smiles>

$2 d$<smiles>O=C1CCCC(=O)C1</smiles>

$2 \mathrm{e}$<smiles>CC(=O)CC(C)=O</smiles>

$2 a$<smiles>CC(=O)CC(C)=O</smiles>

2a<smiles>CC(=O)CC(C)=O</smiles>

2a<smiles>O=C(c1ccccc1)c1nnn(-c2ccccc2Sc2ccccc2)c1-c1ccccc1</smiles>

85<smiles>CC(C)(C)C(=O)c1nnn(-c2ccccc2Sc2ccccc2)c1C(C)(C)C</smiles>

3d<smiles>O=C1CCCc2c1nnn2-c1ccccc1</smiles>

$3 e$<smiles>CC(=O)c1nnn(-c2ccccc2[Se]c2ccc(C)cc2)c1C</smiles>

$3 f$<smiles>CC(=O)c1nnn(-c2ccccc2[Se]c2ccccc2C)c1C</smiles>

$3 g$<smiles>CC(=O)c1nnn(-c2ccccc2[Se]c2ccc(Cl)cc2)c1C</smiles>

$3 \mathrm{~h}$ 
Table 2: Scope of substrates: Variation of the aryl azidophenyl selenides $\mathbf{1}$ and 1,3 -diketones $2 .^{\text {a }}$ (continued)

9<smiles>Nc1ccccc1[Se]c1cccc(C(F)(F)F)c1</smiles>

$1 e$

10<smiles>[N-]c1ccc([Se]c2ccccc2)cc1</smiles>

$1 f$<smiles>CC(=O)CC(C)=O</smiles>

2a<smiles>CC(=O)CC(C)=O</smiles>

2a<smiles>CC(=O)c1nnn(-c2ccccc2[Se]c2cccc(C(F)(F)F)c2)c1C</smiles>

$3 \mathbf{i}$

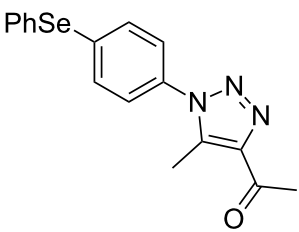

3j

aReactions were performed with aryl azidophenyl selenides $1 \mathbf{a}-\mathbf{f}(0.3 \mathrm{mmol})$ and 1,3 -diketones $2 \mathbf{a}-\mathbf{e}(0.3 \mathrm{mmol})$, using Et ${ }_{2} \mathrm{NH}(1 \mathrm{~mol} \%)$ as catalyst in

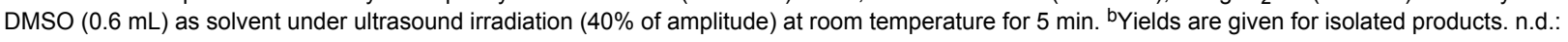
not detected.

[33], amides 3m,n [34] and nitriles 3o,p [36] were obtained in good yields (Scheme 3 ) after 5 minutes reaction under ultrasound irradiation $(40 \%$ of amplitude) at room temperature.
Comparing these results with already published ones under conventional conditions, our methodology using ultrasound irradiation affords the products in 5 minutes and in comparable<smiles>Nc1ccccc1Sc1ccccc1</smiles>

1a<smiles>[R]C(=O)CC(C)(C)C</smiles>

2f-k

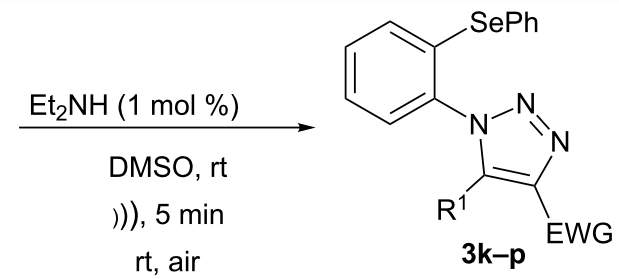<smiles>CCOC(=O)c1nnn(-c2ccccc2[Se]c2ccccc2)c1C</smiles><smiles>Cc1c(C(=O)Nc2ccccc2)nnn1-c1ccccc1Sc1ccccc1</smiles><smiles>N#Cc1nnn(-c2ccccc2S(=O)(=O)c2ccccc2)c1-c1ccccc1</smiles>

3k

$3 \mathrm{~m}$

$89 \%$ $88 \%$<smiles>C/C=C\Cc1ccccc1-c1ccccc1-n1nnc(C(=O)OCC)c1-c1ccccc1</smiles><smiles>Cc1ccc(NC(=O)c2nnn(-c3ccccc3Sc3ccccc3)c2C)cc1</smiles>

$86 \%$<smiles>Cc1ccc(-c2c(C#N)nnn2-c2ccccc2Sc2ccccc2)cc1</smiles> 
yields while the other methods mostly provide the products in times above 60 minutes [33,34,36].

\section{Conclusion}

In summary, we have described the use of sonochemistry in the organocatalytic enamine-azide [3 +2$]$ cycloaddition between 1,3-diketones and aryl azidophenyl selenides. These sonochemical promoted reactions were found to be amenable to a range of 1,3-diketones or aryl azidophenyl selenides, providing an efficient access to novel selenium-containing 1,2,3-triazole compounds in good to excellent yields, in a few minutes of reaction at room temperature. The protocol was extended to activated ketones and selanyltriazoyl carboxylates, with carboxamides and carbonitriles synthesized in high yields and short times of reaction.

\section{Experimental}

\section{General information}

The reactions were monitored by TLC carried out on Merck silica gel $\left(60 \mathrm{~F}_{254}\right)$ by using UV light as visualizing agent and $5 \%$ vanillin in $10 \% \mathrm{H}_{2} \mathrm{SO}_{4}$ and heat as developing agents. Baker silica gel (particle size $0.040-0.063 \mathrm{~mm}$ ) was used for flash chromatography. A Cole Parmer-ultrasonic processor Model CPX 130, with a maximum power of $130 \mathrm{~W}$, operating at an amplitude of $40 \%$ and a frequency of $20 \mathrm{kHz}$ was used. The temperature of the reaction was monitored using an Incoterm digital infrared thermometer Model Infraterm (Brazil) (in most reactions the temperature was in the range between 60 and $65{ }^{\circ} \mathrm{C}$ ). Proton nuclear magnetic resonance spectra $\left({ }^{1} \mathrm{H}\right.$ NMR) were obtained at $400 \mathrm{MHz}$ on Bruker DPX 400 spectrometer. Spectra were recorded in $\mathrm{CDCl}_{3}$ solutions. Chemical shifts are reported in ppm, referenced to tetramethylsilane (TMS) as the external reference. Coupling constants $(J)$ are reported in Hertz. Abbreviations to denote the multiplicity of a particular signal are s (singlet), d (doublet), $t$ (triplet), $\mathrm{q}$ (quartet) and $\mathrm{m}$ (multiplet). Carbon-13 nuclear magnetic resonance spectra $\left({ }^{13} \mathrm{C}\right.$ NMR) were obtained at $100 \mathrm{MHz}$ on Bruker DPX 400 spectrometer. Chemical shifts are reported in ppm, referenced to the solvent peak of $\mathrm{CDCl}_{3}$. Low-resolution mass spectra were obtained with a Shimadzu GC-MS-QP2010 mass spectrometer. High resolution mass spectra (HRMS) were recorded on a Bruker Micro TOF-QII spectrometer 10416.

\section{General procedure for the synthesis of selanyltriazoles 3a-r under ultrasound irradi- ation}

Aryl azidophenyl selenides 1a-f $(0.3 \mathrm{mmol})$, activated ketones 2a-k (0.3 mmol), Et ${ }_{2} \mathrm{NH}(1 \mathrm{~mol} \%)$ and DMSO $(0.6 \mathrm{~mL})$ were added to a glass tube. The ultrasound probe was placed in a glass vial containing the reaction mixture. The amplitude of the ultrasound waves was fixed in $40 \%$. Then, the reaction mixture was sonicated for $5 \mathrm{~min}$. The crude product obtained was subsequently purified by column chromatography on silica gel using a mixture of hexane/ethyl acetate (5:1) as eluent to afford the desired products $\mathbf{3 a}-\mathbf{p}$.

\section{Supporting Information}

\section{Supporting Information File 1}

Experimental and analytical data.

[http://www.beilstein-journals.org/bjoc/content/

supplementary/1860-5397-13-68-S1.pdf]

\section{Acknowledgements}

We thank the CNPq (Grants 306430/2013-4, 400150/2014-0 and 447595/2014-8), CAPES and FAPERGS (PRONEM 6/ 2551-0000240-1) for the financial support. Rafael Luque gratefully acknowledges support from Ciência sem Fronteiras Program (Grant 303415/2014-2) as Visiting Scientist to Universidade Federal de Pelotas, RS.

\section{References}

1. Dehaen, W.; Bakulev, V. A. Chemistry of 1,2,3-triazoles, 1st ed.; Springer International Publishing: New York, 2014.

2. For a set of reviews in this area see the themed issue: Click chemistry: function follows form, in Chem. Soc. Rev. 2010, 39, 1221. doi:10.1039/C003926H

3. For a set of reviews in this area see the themed issue: Bioorthogonal Chemistry in Biology, in Acc. Chem. Res. 2011, 44, 651. doi:10.1021/ar200193f

4. Nandivada, H.; Jiang, X.; Lahann, J. Adv. Mater. 2007, 19, 2197. doi:10.1002/adma.200602739

5. Lee, B. S.; Lee, J. K.; Kim, W.-J.; Jung, Y. H.; Sim, S. J.; Lee, J.; Choi, I. S. Biomacromolecules 2007, 8, 744. doi:10.1021/bm060782+

6. Deobald, A. M.; Camargo, L. R. S.; Alves, D.; Zukerman-Schpector, J.; Corrêa, A. G.; Paixão, M. W. Synthesis 2011, 4003. doi:10.1055/s-0031-1289606

7. Pérez-Labrada, K.; Brovard, I.; Morera, C.; Estévez, F.; Bermejo, J.; Rivera, D. G. Tetrahedron 2011, 67, 7713. doi:10.1016/j.tet.2011.08.003

8. Días, D. D.; Rajagopal, K.; Strable, E.; Schneider, J.; Finn, M. G. J. Am. Chem. Soc. 2006, 128, 6056. doi:10.1021/ja061251w

9. Astruc, D.; Liang, L.; Rapakousiou, A.; Ruiz, J. Acc. Chem. Res. 2012, 45, 630. doi:10.1021/ar200235m

10. Tasdelen, M. A.; Yilmaz, G.; Iskin, B.; Yagci, Y. Macromolecules 2012, 45, 56. doi:10.1021/ma202438w

11. Font, D.; Jimeno, C.; Pericàs, M. A. Org. Lett. 2006, 8, 4653. doi:10.1021/ol061964j

12. Font, D.; Bastero, A.; Sayalero, S.; Jimeno, C.; Pericàs, M. A. Org. Lett. 2007, 9, 1943. doi:10.1021/ol070526p

13. Font, D.; Sayalero, S.; Bastero, A.; Jimeno, C.; Pericàs, M. A. Org. Lett. 2008, 10, 337. doi:10.1021/ol702901z

14. Lallana, E.; Riguera, R.; Fernandez-Megia, E. Angew. Chem., Int. Ed. 2011, 50, 8794. doi:10.1002/anie.201101019

15. Hong, V.; Presolski, S. I.; Ma, C.; Finn, M. G. Angew. Chem., Int. Ed. 2009, 48, 9879. doi:10.1002/anie.200905087 
16. Huisgen, R. Angew. Chem. 1963, 75, 604. doi:10.1002/ange.19630751304

17. Huisgen, R. Proc. Chem. Soc., London 1961, 357. doi:10.1039/PS9610000357

18. Huisgen, R. In 1,3-Dipolar Cycloaddition Chemistry; Padwa, A., Ed.; Wiley: New York, 1984; Vol. 1, 1.

19. Huisgen, R. Pure Appl. Chem. 1989, 61, 613. doi:10.1351/pac198961040613

20. Rostovtsev, V. V.; Green, L. G.; Fokin, V. V.; Sharpless, K. B. Angew. Chem., Int. Ed. 2002, 41, 2596. doi:10.1002/1521-3773(20020715)41:14<2596::AID-ANIE2596>3.0.CO ;2-4

21. Tornøe, C. W.; Christensen, C.; Meldal, M. J. Org. Chem. 2002, 67, 3057. doi:10.1021/jo011148j

22. Krasiński, A.; Radić, Z.; Manetsch, R.; Raushel, J.; Taylor, P.; Sharpless, K. B.; Kolb, H. C. J. Am. Chem. Soc. 2005, 127, 6686. doi:10.1021/ja043031t

23. Lee, L. V.; Mitchell, M. L.; Huang, S.-J.; Fokin, V. V.; Sharpless, K. B.; Wong, C.-H. J. Am. Chem. Soc. 2003, 125, 9588. doi:10.1021/ja0302836

24. Hein, J. E.; Tripp, J. C.; Krasnova, L. B.; Sharpless, K. B.; Fokin, V. V. Angew. Chem., Int. Ed. 2009, 48, 8018-8021. doi:10.1002/anie.200903558

25. Zhang, L.; Chen, X.; Xue, P.; Sun, H. H. Y.; Williams, I. D.; Sharpless, K. B.; Fokin, V. V.; Jia, G. J. Am. Chem. Soc. 2005, 127, 15998. doi:10.1021/ja054114s

26. Boren, B. C.; Narayan, S.; Rasmussen, L. K.; Zhang, L.; Zhao, H.; Lin, Z.; Jia, G.; Fokin, V. V. J. Am. Chem. Soc. 2008, 130, 8923. doi:10.1021/ja0749993

27. McNulty, J.; Keskar, K.; Vemula, R. Chem. - Eur. J. 2011, 17, 14727. doi:10.1002/chem.201103244

28. McNulty, J.; Keskar, K. Eur. J. Org. Chem. 2012, 5462. doi:10.1002/ejoc.201200930

29. Ding, S.; Jia, G.; Sun, J. Angew. Chem., Int. Ed. 2014, 53, 1877. doi:10.1002/anie.201309855

30. Lima, C. G. S.; Ali, A.; van Berkel, S. S.; Westermann, B.; Paixão, M. W. Chem. Commun. 2015, 51, 10784. doi:10.1039/C5CC04114G

31. Ramasastry, S. S. V. Angew. Chem., Int. Ed. 2014, 53, 14310-14312. doi:10.1002/anie.201409410

32. John, J.; Thomas, J.; Dehaen, W. Chem. Commun. 2015, 51, 10797. doi:10.1039/C5CC02319J

33. Seus, N.; Gonçalves, L. C.; Deobald, A. M.; Savegnago, L.; Alves, D.; Paixão, M. W. Tetrahedron 2012, 68, 10456. doi:10.1016/j.tet.2012.10.007

34. Seus, N.; Goldani, B.; Lenardão, E. J.; Savegnago, L.; Paixão, M. W.; Alves, D. Eur. J. Org. Chem. 2014, 1059. doi:10.1002/ejoc.201301547

35. Saraiva, M. T.; Costa, G. P.; Seus, N.; Schumacher, R. F.; Perin, G.; Paixão, M. W.; Luque, R.; Alves, D. Org. Lett. 2015, 17, 6206. doi:10.1021/acs.orglett.5b03196

36. Savegnago, L.; do Sacramento, M.; Brod, L. M. P.; Fronza, M. G.; Seus, N.; Lenardão, E. J.; Paixão, M. W.; Alves, D. RSC Adv. 2016, 6, 8021. doi:10.1039/C5RA22445D

37. Saraiva, M. T.; Krüger, R.; Baldinotti, R. S. M.; Lenardão, E. J.; Luchese, C.; Savegnago, L.; Wilhelm, E. A.; Alves, D. J. Braz. Chem. Soc. 2016, 27, 41. doi:10.5935/0103-5053.20150239

38. Alberto, E. E.; Braga, A. L. In Selenium and Tellurium Chemistry From Small Molecules to Biomolecules and Materials; Derek, W. J.; Risto, L., Eds.; Springer-Verlag: Berlin Heidelberg, 2011.
39. Wirth, T. Organoselenium Chemistry: Synthesis and Reactions; Wiley-VCH: Weinheim, 2011. doi:10.1002/9783527641949

40. Menezes, P. H.; Zeni, G. Vinyl Selenides. Patai's Chemistry of Functional Groups; John Wiley \& Sons: Oxford, 2011. doi:10.1002/9780470682531.pat0568

41. Perin, G.; Lenardão, E. J.; Jacob, R. G.; Panatieri, R. B. Chem. Rev. 2009, 109, 1277. doi:10.1021/cr8004394

42. Perin, G.; Alves, D.; Jacob, R. G.; Barcellos, A. M.; Soares, L. K.; Lenardão, E. J. ChemistrySelect 2016, 1, 205. doi:10.1002/slct.201500031

43. Freudendahl, D. M.; Santoro, S.; Shahzad, S. A.; Santi, C.; Wirth, T. Angew. Chem., Int. Ed. 2009, 48, 8409. doi:10.1002/anie.200903893

44. Rampon, D. S.; Santos, F. S.; Descalzo, R. R.; Toldo, J. M.; Gonçalves, P. F. B.; Schneider, P. H.; Rodembusch, F. S. J. Phys. Org. Chem. 2014, 27, 336. doi:10.1002/poc.3229

45. Rampon, D. S.; Rodembusch, F. S.; Schneider, J. M. F. M.; Bechtold, I. H.; Gonçalves, P. F. B.; Merlo, A.; Schneider, P. H. J. Mater. Chem. 2010, 20, 715. doi:10.1039/B917366H

46. Samb, I.; Bell, J.; Toullec, P. Y.; Michelet, V.; Leray, I. Org. Lett. 2011, 13, 1182. doi:10.1021/ol200066p

47. Goswami, S.; Hazra, A.; Chakrabarty, R.; Fun, H.-K. Org. Lett. 2009, 11, 4350. doi:10.1021/ol901737s

48. Tang, B.; Xing, Y.; Li, P.; Zhang, N.; Yu, F.; Yang, G. J. Am. Chem. Soc. 2007, 129, 11666. doi:10.1021/ja072572q

49. Balaguez, R. A.; Ricordi, V. G.; Duarte, R. C.; Toldo, J. M.; Santos, C. M.; Schneider, P. H.; Gonçalves, P. F. B.; Rodembusch, F. S.; Alves, D. RSC Adv. 2016, 6, 49613. doi:10.1039/C6RA04157D

50. Nogueira, C. W.; Rocha, J. B. T. Organoselenium and organotellurium compounds: Toxicology and pharmacology. In Patai's Chemistry of Functional Groups; Rappoport, Z., (Org)., Ed.; Wiley: Chichester, 2011. doi:10.1002/9780470682531.pat0567

51. Santoro, S.; Azeredo, J. B.; Nascimento, V.; Sancineto, L.; Braga, A. L.; Santi, C. RSC Adv. 2014, 4, 31521. doi:10.1039/C4RA04493B

52. Nogueira, C. W.; Zeni, G.; Rocha, J. B. T. Chem. Rev. 2004, 104, 6255. doi:10.1021/cr0406559

53. Tiecco, M.; Testaferri, L.; Santi, C.; Tomassini, C.; Marini, F.; Bagnoli, L.; Temperini, A. Angew. Chem., Int. Ed. 2003, 42, 3131. doi:10.1002/anie.200351229

54. Back, T. G.; Bethell, R. J.; Parvez, M.; Taylor, J. A.; Wehrli, D. J. Org. Chem. 1999, 64, 7426. doi:10.1021/jo990730t

55. Stefani, H. A.; Silva, N. C. S.; Manarin, F.; Lüdtke, D. S.; Zukerman-Schpector, J.; Madureira, L. S.; Tiekink, E. R. T. Tetrahedron Lett. 2012, 53, 1742. doi:10.1016/j.tetlet.2012.01.102

56. Stefani, H. A.; Leal, D. M.; Manarin, F. Tetrahedron Lett. 2012, 53, 6495. doi:10.1016/j.tetlet.2012.09.062

57. Deobald, A. M.; Camargo, L. R. S.; Hörner, M.; Rodrigues, O. E. D.; Alves, D.; Braga, A. L. Synthesis 2011, 2397. doi:10.1055/s-0030-1260083

58. Seus, N.; Saraiva, M. T.; Alberto, E. E.; Savegnago, L.; Alves, D. Tetrahedron 2012, 68, 10419. doi:10.1016/j.tet.2012.07.019

59. Saraiva, M. T.; Seus, N.; de Souza, D.; Rodrigues, O. E. D.; Paixão, M. W.; Jacob, R. G.; Lenardão, E. J.; Perin, G.; Alves, D. Synthesis 2012, 44, 1997. doi:10.1055/s-0031-1291135

60. Donato, F.; de Gomes, M. G.; Goes, A. T. R.; Seus, N.; Alves, D.; Jesse, C. R.; Savegnago, L. Life Sci. 2013, 93, 393. doi:10.1016/j.lfs.2013.07.024 
61. da Cruz, E. H. G.; Silvers, M. A.; Jardim, G. A. M.; Resende, J. M.; Cavalcanti, B. C.; Bomfim, I. S.; Pessoa, C.; de Simone, C. A.; Botteselle, G. V.; Braga, A. L.; Nair, D. K.; Namboothiri, I. N. N.; Boothman, D. A.; da Silva Júnior, E. N. Eur. J. Med. Chem. 2016, 122, 1. doi:10.1016/j.ejmech.2016.06.019

62. Mojtahedi, M. M.; Abaee, M. S. Ultrasound applications in synthetic organic chemistry. In Handbook on Applications of Ultrasound Sonochemistry for Sustainability; Chen, D.; Sharma, S. K.; Mudhoo, A. Eds.; CRC Press: New York, 2012; pp $281 \mathrm{ff}$.

63. Li, Z.; Hong, J.; Zhou, X. Tetrahedron 2011, 67, 3690. doi:10.1016/j.tet.2011.03.067

64. Cravotto, G.; Cintas, P. Chem. Soc. Rev. 2006, 35, 180. doi:10.1039/B503848K

65. Mason, T. J. Ultrason. Sonochem. 2007, 14, 476. doi:10.1016/j.ultsonch.2006.10.008

66. Nüchter, M.; Ondruschka, B.; Jungnickel, A.; Müller, U. J. Phys. Org. Chem. 2000, 13, 579 doi:10.1002/1099-1395(200010)13:10<579::AID-POC272>3.0.CO;2-M

67. Mason, T. J. Chem. Soc. Rev. 1997, 26, 443. doi:10.1039/cs9972600443

68. Cravotto, G.; Fokin, V. V.; Garella, D.; Binello, A.; Boffa, L.; Barge, A. J. Comb. Chem. 2010, 12, 13. doi:10.1021/cc900150d

69. Mady, M. F.; Awad, G. E. A.; Jørgensen, K. B. Eur. J. Med. Chem. 2014, 84, 433. doi:10.1016/j.ejmech.2014.07.042

70. Marzag, H.; Alaoui, S.; Amdouni, H.; Martin, A. R.; Bougrin, K.; Benhida, R. New J. Chem. 2015, 39, 5437. doi:10.1039/C5NJ00624D

71. Nallapati, S. B.; Sreenivas, B. Y.; Bankala, R.; Parsa, K. V. L.; Sripelly, S.; Mukkanti, K.; Pal, M. RSC Adv. 2015, 5, 94623. doi:10.1039/C5RA20380E

72. Naeimi, H.; Dadashzadeh, S.; Moradian, M. Res. Chem. Intermed. 2015, 41, 2687. doi:10.1007/s11164-013-1379-6

73. Stefani, H. A.; Canduzini, H. A.; Manarin, F. Tetrahedron Lett. 2011, 52, 6086. doi:10.1016/j.tetlet.2011.09.004

74. Jiang, Y.; Chen, X.; Qu, L.; Wang, J.; Yuan, J.; Chen, S.; Li, X.; Qu, C. Ultrason. Sonochem. 2011, 18, 527. doi:10.1016/j.ultsonch.2010.09.009

75. Xavier, D. M.; Goldani, B. S.; Seus, N.; Jacob, R. G.; Barcellos, T.; Paixão, M. W.; Luque, R.; Alves, D. Ultrason. Sonochem. 2017, 34 , 107. doi:10.1016/j.ultsonch.2016.05.007

\section{License and Terms}

This is an Open Access article under the terms of the Creative Commons Attribution License (http://creativecommons.org/licenses/by/4.0), which permits unrestricted use, distribution, and reproduction in any medium, provided the original work is properly cited.

The license is subject to the Beilstein Journal of Organic Chemistry terms and conditions: (http://www.beilstein-journals.org/bjoc)

The definitive version of this article is the electronic one which can be found at: doi:10.3762/bjoc. 13.68 